\title{
Investigation of ACE Genome Insertion/Deletion Correlation with Immunohistochemical Profile in Pituitary Adenomas
}

\author{
Pituiter Adenomunda Immünobistokimyasal Profil ile ACE Geni \\ Insersiyon/Delesyon Korelasyonunun Incelenmesi
}

Murat ALTAS ${ }^{1}$, Omer Faruk BAYRAK ${ }^{2}$, Alpay SEREFHAN ${ }^{3}$, Gokalp SILAV ${ }^{4}$, Kerim Kenan COSKUN ${ }^{3}$, Ajlan $\mathrm{CERCI}^{3}$, Nejat $\mathrm{ISIK}^{3}$, İlhan ELMACI ${ }^{4}$

${ }^{1}$ Mustafa Kemal University, Faculty of Medicine, Department of Neurosurgery, Antakya, Turkey

${ }^{2}$ Yeditepe University, Faculty of Medicine, Department of Genetics and BioEngineering, Istanbul, Turkey

${ }^{3}$ Goztepe Education and Research Hospital, Department of Neurosurgey, Istanbul, Turkey

${ }_{4}^{4}$ Acibadem University, Faculty of Medicine, Department of Neurosurgey, Istanbul, Turkey

Corresponding Author: Murat ALTAS / E-mail: draltasmurat@yahoo.com

\begin{abstract}
AIM: The deletion polymorphism of the angiotensin-converting enzyme (ACE) genome causes neoplastic development in several organs by increasing the angiotensin 2 (A2) formation. In this study, we aimed to identify the ACE genome insertion/deletion polymorphism in pituitary adenomas and to compare it with the control group.

MATERIAL and METHODS: Patients operated for pituitary adenomas were included in the study. Genomic DNA was extracted from tumoral tissues and peripheral blood samples of the patients by using the Miller method. Primary sequence was selected via targeting the polymorphic region of intron 16 of ACE genome 17q23. DNA samples were multiplied by PCR using HACE3s and HACE3as primers.

RESULTS: Twenty-one operated cases were studied. In the study group; $44 \%$ of the patients were identified as D/D, 33\% of them as I/D and $23 \%$ of them as $\mathrm{I} / \mathrm{I}$. In $60 \%$, D allele was identified. According to immunohistochemical investigation, we found that $100 \%$ of the patients with Cushing adenoma were D/D alleles.

CONCLUSION: Presence of high rate of ACE genome deletion in patients with pituitary adenoma and grade 3-4 patients suggest that ACE genome polymorphism can be a risk factor for the development of pituitary adenomas.
\end{abstract}

KEYWORDS: Angiotensin-converting enzyme, Pituitary adenomas, Gene

öz

AMAÇ: Anjiotensin Converting Enzim (ACE) genindeki bir delesyon Anjiotensin 2 de bir artış sağlayarak çeşitli organlarda neoplastik gelişmelere neden olur. Biz bu çalışmada hipofiz adenomlu hastalarda ACE geninde insersiyon /delesyon polimorfizmini belirleyerek kontrol grubuyla karşılaştırmayı amaçladık.

YÖNTEM ve GEREÇLER: Çalışmaya hipofiz adenomu nedeniyle opere edilen hastaların hem tümör dokusundan hemde venöz kandan Miller metodu kulanarak örnekler alındı ve DNA ları izole edildi. Sekans çalışması için 17q 23 deki ACE geninin intron 16 bölgesi hedef seçildi. DNA örnekleri için,HACE 3s, HACE 3as primerleri PCR da kullanıldı.

BULGULAR: Opere edilen 21 hasta çalışmaya dahil edildi. Çalışma grubunda hastaların \%44 de D/D alleli, \%33 de I/D alleli, \%23 de I/I alleli tanımlandı.Tüm çalışma grubunda \%60 oranında D alleli tanımlandı. İmmünohistokimyasal profile göre ise Cushing adenomunda \%100 oranında D/D polimorfizmi görüldü.

SONUÇ: Kontrol grubuyla karşılaştıııldığında özellikle Grade 3-4 olan hipofiz adenomlu hastalarda yüksek oranda ACE geninde delesyon varlığı hipofiz adenomu gelişiminde ACE geninin bir risk faktörü olabileceğini düşündürmektedir.

ANAHTAR SÖZCÜKLER: Anjiotensin-converting enzim, Hipofiz adenomu, Gen

\section{INTRODUCTION}

Pituitary tumors constitute $10 \%$ of all intracranial tumors and they are associated with local mass effects and marked morbidity due to hormonal secretion (1). Many subjects regarding molecular pathogenesis of hypophysis adenomas have not been clarified yet. Studies performed recently show that the pathogenesis of pituitary tumor is rather heterogeneous (2). Recent developments in pituitary tumor genetics made pituitary gland an ideal target for development of new molecular therapies. 
We can classify the factors responsible for development of pituitary tumors in four groups: Oncogenes, Tumor suppressor genes, Transcription factors, Autocrine paracrine stimulation (3). All the components of RAS (renin angiotensin system) are located in the pituitary gland $(4,5)$. Many studies have shown that RAS contributes to regulation of hormonal secretion in both the hypothalamus and pituitary gland $(6,7,8)$ and also causes activation of protooncogenes through MAP kinase pathway. In animal models, it was shown that RAS components accelerated neovascularization by accelerating the smooth muscle cell proliferation. This is gradually increasing interest in the role of RAS in management of angiogenesis in neoplastic developments $(9,10,11)$. Angiotensin-converting enzyme (ACE) is among zinc metallopeptidase enzyme family and responsible for conversion of Angiotensin 1 to Angiotensin 2. ACE gene is encoded by a $21 \mathrm{~Kb}$ gene that consists of 26 exons and is located on the long arm of $17^{\text {th }}$ chromosome. A polymorphism of the ACE genome involves the insertion (I) or deletion (D) of a 287 base pairs indicated in intron 16. It is known that efficacy of ACE is maximal in homozygote individuals (D/D) and minimal in individuals' homozygote for insertion type polymorphism (I/I). Therefore, individuals with higher ACE level, namely who are homozygote for D allele, are exposed to risks associated with angiotensin 2 much more (12-19).

All the components of RAS are located in the pituitary gland and $A 2$ is produced locally. As it is known, hypophyseal adenomas are less vascular than normal hypophysis, and therefore angiogenesis in hypophyseal adenomas is an important model for tumor biology. The aim of the present study was to determine the genotype distribution and allele frequency in ACE genome polymorphism of the patients with pituitary tumors.

\section{MATERIAL and METHODS}

\section{Patients}

Twenty-one patients who underwent surgical excision of a hypophyseal adenoma were included in the study and the extent of invasion of each hypophyseal adenoma was assessed radiologically and immunohistochemically. Five venous blood samples were taken from each patient and DNA isolation was performed in both the peripheral blood samples and pathologic specimens. For the control group, 5 venous blood samples were taken from 20 healthy volunteers of similar age and DNA isolation was performed from the peripheral blood samples only. Volume was calculated by measuring the three-dimensional lengths of tumor masses on MRI. Cases were classified according to the Hardy-Wezina classification (Table I).

\section{Preparation of Genomic Deoxyribonucleic Acid}

Five milliliters of venous blood sample were collected in tubes containing either acid citrate-dextrose or ethylene diamine tetra acetic acid and were shipped at ambient temperature by overnight courier to the laboratory. The deoxyribonucleic acid (DNA) was prepared from whole-blood lyses of nuclei, which was accomplished by using sodium dodecyl sulfate and proteinase $\mathrm{K}$, followed by phenol-chloroform extraction and ethanol precipitation. The DNA was resuspended in water containing $10 \mathrm{mmol} / \mathrm{L}$ Tris $(\mathrm{pH} 8)$ and $0.1 \mathrm{mmol} / \mathrm{L}$ ethylene diamine tetra acetic acid. Samples were divided into aliquots and diluted to $200 \mathrm{~g} / \mathrm{ml}$, after which they were frozen at $-80^{\circ} \mathrm{C}$.

\section{Genotyping Analysis}

DNA isolation was done by taking peripheral venous blood sample from all family members and polymerase chain reactions (PCR) were used to detect insertion: deletion (I/D) polymorphisms of the ACE genome. Genomic DNA, dNTPs and TaqDNA polymerase were used for PCR mixture and primers of HACE3s and HACE3as were used for ACE. The PCR steps were as the following: initial denaturation step at $94^{\circ} \mathrm{C}$ for 4 minutes, followed by 36 cycles of denaturation at $94^{\circ} \mathrm{C}$ for 50 seconds, annealing at $58^{\circ} \mathrm{C}$ for 30 seconds, extension at $72^{\circ} \mathrm{C}$ for 60 seconds and a final extension at $72^{\circ} \mathrm{C}$ for 5 minutes. Amplicons obtained were $D$ and I alleles which resulted in 319-bp and 597-bp, respectively. For the verification of these results, another PCR study for the amplification of the $D$ allele was performed. Each sample found to have the D/D genotype was subjected to a second round of PCR amplification with an insertion of specific primer HACE5 forward (5'-TGGGACCACAGCGCCCGCCACTAC-3') and HACE5 reverse (5'- TCGCCAGCCCTCCCATGCCCATAA-3') under the same PCR steps except for an annealing temperature of $60^{\circ} \mathrm{C}$. Only the I allele yielded a 335-bp amplicon in the PCR study. PCR products were separated on $2 \%$ agarose gel with ethidium bromide staining, visualized by ultraviolet transillumination and stored in digital form (Figure 1). Possible mistyping of the ACE I/D genotype as D/D was controlled by the inclusion of dimethyl sulfoxide in the PCR reaction.

\section{Statistical Analysis}

All statistical analyses were performed by using 2007 \& PASS NCSS Statistical Software 2008 (Utah, USA). The Chi-square test was used to evaluate the data of the study. Statistical significance was defined to be a $p$ value of $<0.05$.

\section{RESULT}

The ages of the cases varied between 9 and 69 years and the mean age was $33.31 \pm 14.86$ years. Fifty-eight of the cases $(70.7 \%)$ were female and 24 of them $(29.3 \%)$ male. $4.8 \%$ of the cases were Grade I, $28.6 \%$ Grade II, $47.6 \%$ Grade III and $19 \%$ Grade IV. In immunohistochemical findings, GH was determined at a rate of $33,3 \%$; prolactin $52,4 \%$, TSH $4,8 \%$, ACTH 19,0\%; LH 4,8\% and FSH 4,8\% as pathological (Table II). No statistically significant differences were seen between ACE genotype distributions in pituitary adenoma and control groups ( $p>0,05)$. D/D genotype is high in cases with pituitary adenomas and I/D genotype is high in control cases (Table III). Situation of being pathological of $\mathrm{GH}$, prolactin, $\mathrm{TSH}$, ACTH and LH/FSH findings among immunohistochemical parameters does not show statistically significant difference according to ACE genotype measurements and Allele frequency $(p>0.05)$ (Table IV). There is no statistically 


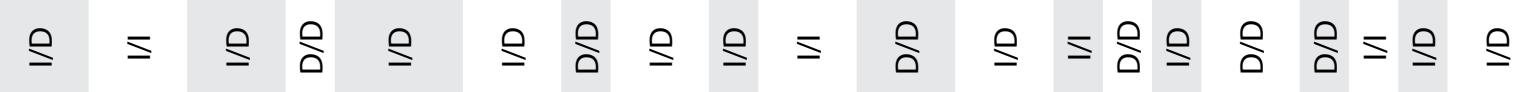

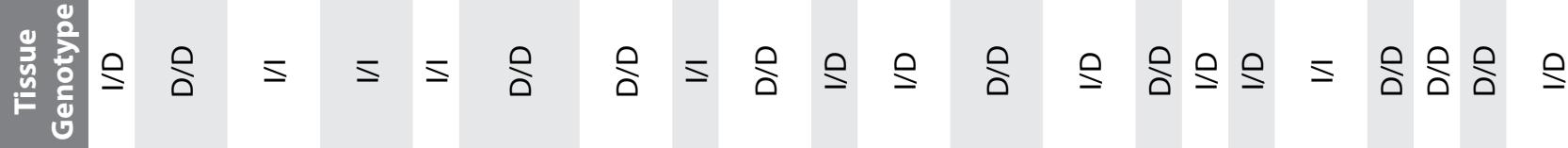
שֶ

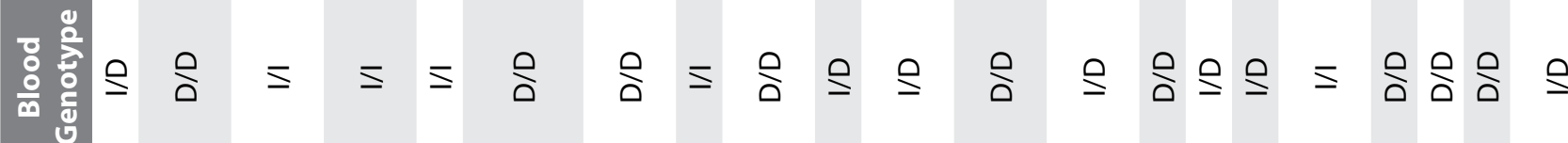
政

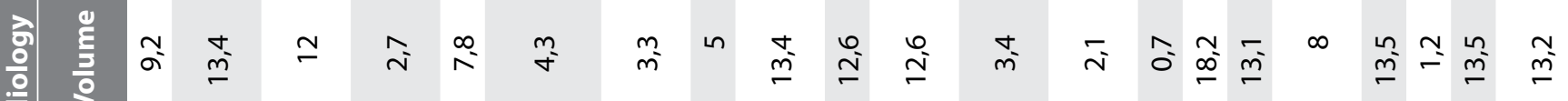
$\stackrel{\sim}{m} m \stackrel{\sim}{=} \stackrel{n}{i} \stackrel{\stackrel{n}{m}}{m} \stackrel{m}{m} \stackrel{\infty}{i} m m \wedge \sim \stackrel{\sim}{=} m \stackrel{n}{m} \stackrel{\infty}{i} m \stackrel{\infty}{0} m m$

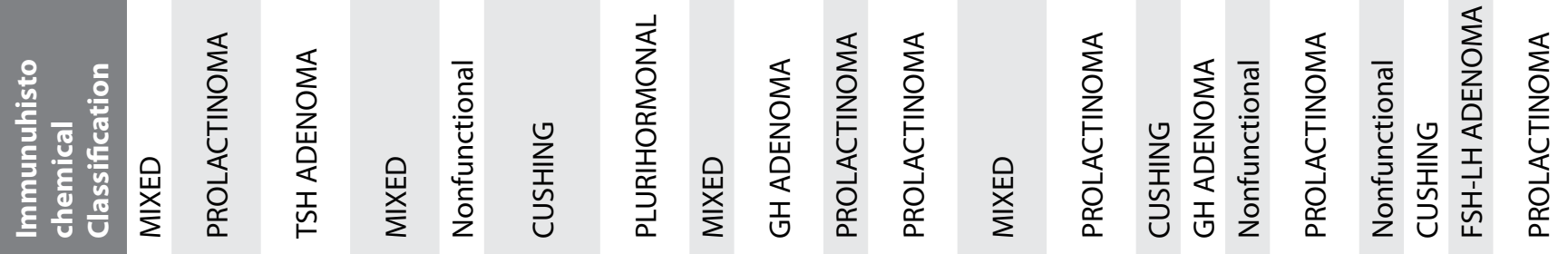

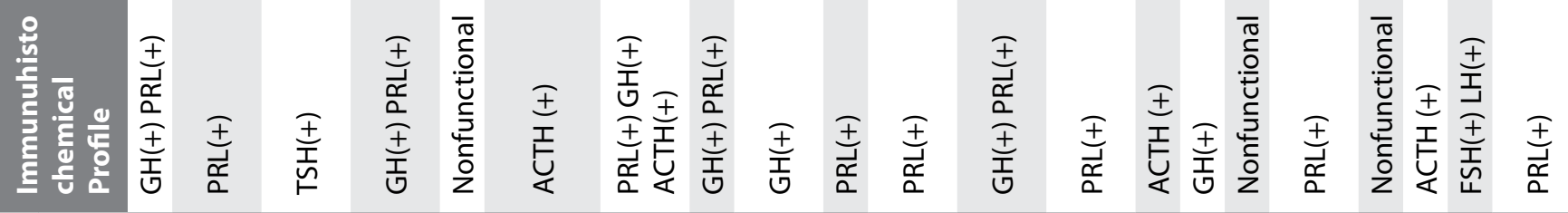

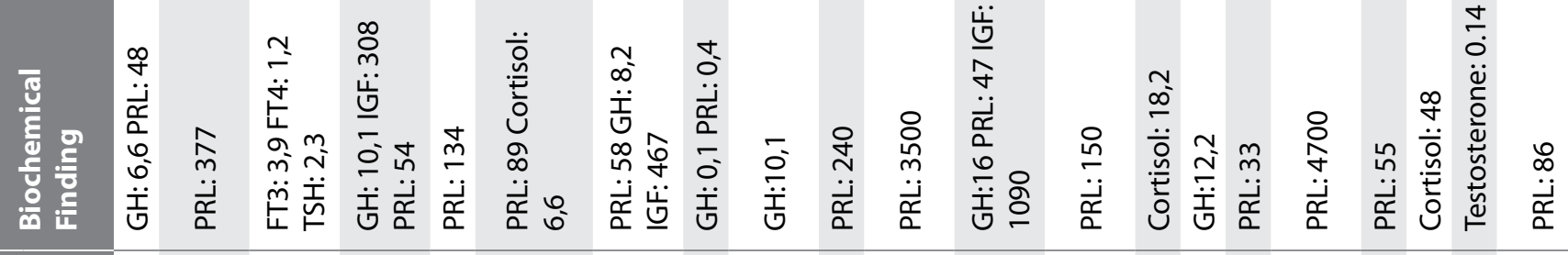

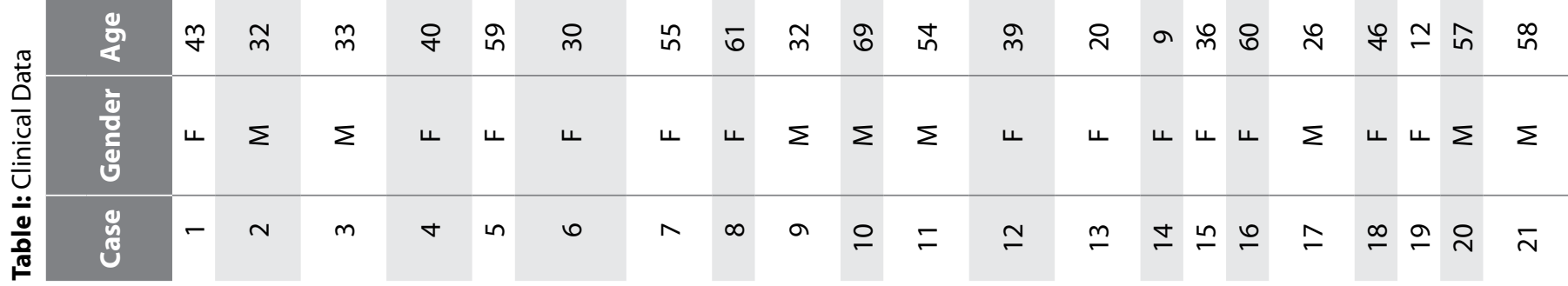


significant difference between volume and grade distribution of the cases according to ACE genotype and Allele frequency ( $p>0.05)$ (Table V).

Table II: Distribution of Rates of Being Pathologic Regarding Immunohistochemical Findings

\begin{tabular}{|l|r|r|}
\hline $\begin{array}{l}\text { Pathologic } \\
\text { Immunohistochemical Profile }\end{array}$ & $\mathbf{n}$ & $\%$ \\
\hline GH & 7 & 33,3 \\
\hline PRL & 11 & 52,4 \\
\hline TSH & 1 & 4,8 \\
\hline ACTH & 4 & 19,0 \\
\hline LH & 1 & 4.8 \\
\hline FSH & 1 & 4.8 \\
\hline
\end{tabular}

Table III: Evaluation of Genotypes According to the Groups

\begin{tabular}{|c|c|c|c|c|c|}
\hline & \multicolumn{3}{|c|}{ ACE Genotype } & \multicolumn{2}{|c|}{ ALLELE } \\
\hline & I/D & D/D & I/I & $\mathbf{I}$ & D \\
\hline Pituitary adenoma n (\%) & $7(\% 33,3)$ & $9(\% 42,9)$ & $5(\% 23,8)$ & $17(\% 40,5)$ & $25(\% 59,5)$ \\
\hline Control Gr n (\%) & $10(\% 50,0)$ & $6(\% 30,0)$ & $4(\% 20,0)$ & $18(\% 45,0)$ & $22(\% 55,0)$ \\
\hline$p$ & \multicolumn{3}{|c|}{0,544} & \multicolumn{2}{|c|}{0,679} \\
\hline
\end{tabular}

Chi-Square test was used.

Table IV: Evaluation of Immunohistochemical Findings According to Genotypes

\begin{tabular}{|c|c|c|c|c|c|c|c|}
\hline & \multicolumn{4}{|c|}{ ACE Genotype } & \multicolumn{3}{|c|}{ ALLELE } \\
\hline & I/D & D/D & $I / I$ & $\mathbf{p}$ & I & D & $\mathbf{p}$ \\
\hline GH; n (\%) & $2(\% 28,6)$ & $3(\% 33,3)$ & $2(\% 40,0)$ & 0,918 & $6(\% 35,3)$ & $8(\% 32,0)$ & 0,824 \\
\hline PRL; n (\%) & $4(\% 57,1)$ & $4(\% 44,4)$ & $3(\% 60,0)$ & 0,816 & $10(\% 58,8)$ & $12(\% 48,0)$ & 0,491 \\
\hline TSH; n (\%) & - & - & $1(\% 20,0)$ & 0,186 & $2(\% 11,8)$ & - & 0,158 \\
\hline АCTH; n (\%) & $1(\% 14,3)$ & $3(\% 33,3)$ & - & 0,291 & $1(\% 5,9)$ & $7(\% 28,0)$ & 0,114 \\
\hline LH/FSH; n (\%) & - & $1(\% 11,1)$ & - & 0,497 & - & $2(\% 8,0)$ & 0,506 \\
\hline
\end{tabular}

Chi-square test was used.

Table V: Volume and Grade Distributions According to Genotypes

\begin{tabular}{|c|c|c|c|c|c|}
\hline & & \multicolumn{2}{|c|}{ Volume } & \multicolumn{2}{|c|}{ Grade } \\
\hline & & Mean & SD & $\begin{array}{c}\text { Grade I+II } \\
\text { n (\%) }\end{array}$ & $\begin{array}{c}\text { Grade III+IV } \\
\text { n (\%) }\end{array}$ \\
\hline \multirow{5}{*}{ ACE Genotype } & I/D & 11,37 & 5,39 & $1(\% 14,3)$ & $6(\% 85,7)$ \\
\hline & $D / D$ & 7,56 & 5,64 & $4(\% 44,4)$ & $5(\% 55,6)$ \\
\hline & $\mathrm{I} / \mathrm{I}$ & 7,10 & 3,50 & $2(\% 40,0)$ & $3(\% 60,0)$ \\
\hline & $p$ & \multicolumn{2}{|c|}{0,475} & \multicolumn{2}{|c|}{0,418} \\
\hline & I & 8,85 & 4,66 & $5(\% 29,4)$ & $12(\% 70,6)$ \\
\hline \multirow{2}{*}{ ALLELE } & D & 8,63 & 5,61 & $9(\% 36,0)$ & $16(\% 64,0)$ \\
\hline & $p$ & \multicolumn{2}{|c|}{0,888} & \multicolumn{2}{|c|}{0,657} \\
\hline
\end{tabular}

Volume distributions in ACE Genotype with Aneway Anowa; ALLEL frequency with student $t$ test; Grade distributions were evaluated with Chi-square test. 


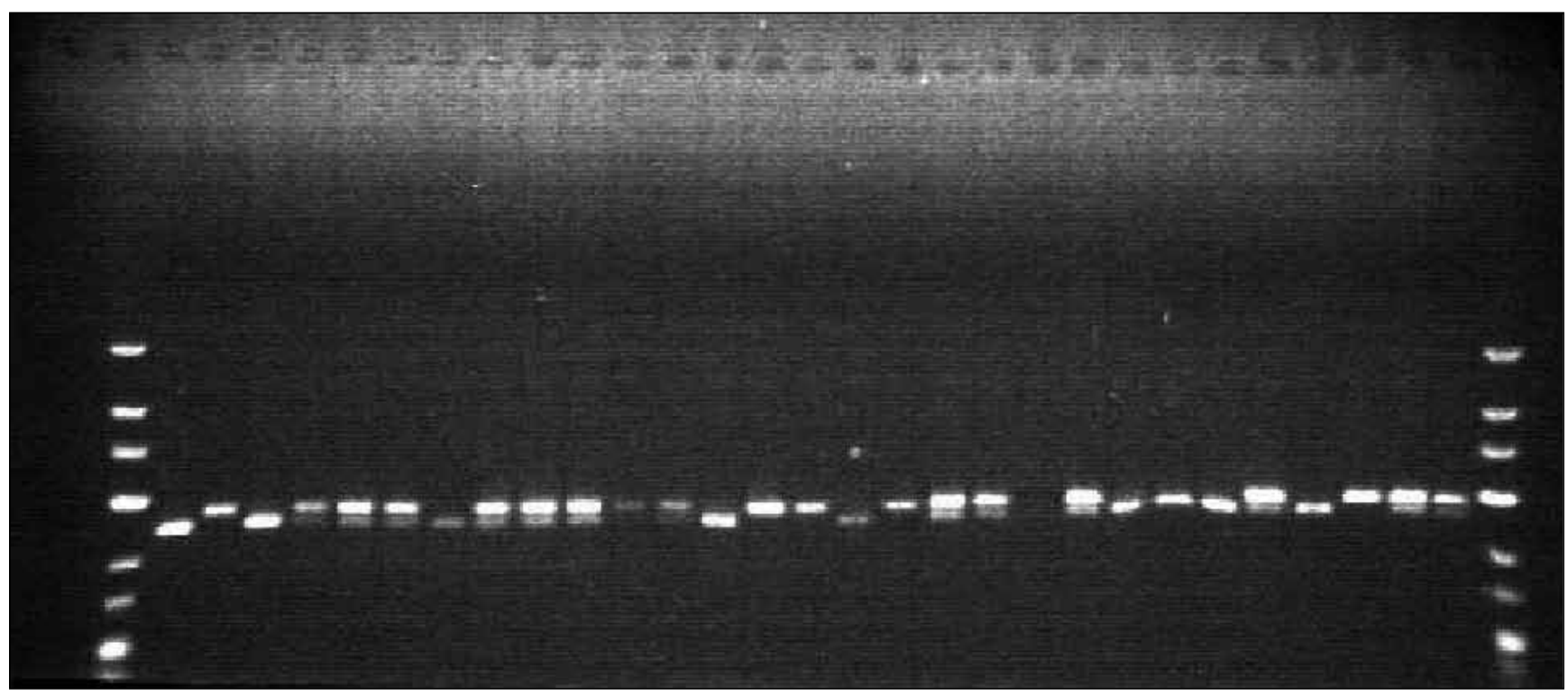

Figure 1: Extracted DNA samples on agarose gel.

Many studies showed that A2 contributed to physiological regulation of prolactin secretion from both hypothalamus and pituitary gland $(6,8)$. One of the possible functions of endogenous A2 system in hypothalamus is to limit the prolactin secretion against environmental or endogenous stimuli. But A2 conducts this function by exhibiting opposite effects in hypothalamus and pituitary gland. A2 increases prolactin secretion in the pituitary gland and mediates the paracrine effect of $\mathrm{GnRH}$ on prolactin secretion $(20,21)$.

In the study performed by Pawlikowski, it was reported that A2 produced locally affected the reproductive functions of the anterior hypophysis and other endocrine organs and A2 regulated the prolactin, $A C T H$ and $\mathrm{LH}$ secretion and expression of AT2 receptors were associated with tumoral neoangiogenesis and it was shown that both AT1 and AT2 receptors played a role in the control of cell proliferation also in induction of apoptosis.

In animal models, it was demonstrated that A2 induced neovascularization by accelerating smooth muscle cell proliferation (12). This situation gradually increases the interest toward the role of $A 2$ in regulation of angiogenesis in neoplastic developments. In addition to this, A2 can behave as mitotic factor by inducing or regulating gene expression in cell cycle progression. Effective blockade of $A 2$ receptor decreases the tumor progression developing due to TGF-B1 (transforming growth factor B1) in vivo (22). Increase of ACE increases G protein synthesis by using MAP (mitogen activated protein) kinase pathway together with growth factor, $\beta$-fibroblast growth factor, fibronectin, platelet derived growth factor ( $\beta-F G F)$, transforming growth factor (TGF- $\beta$ ) and vascular endothelial growth factor (VEGF) $(20,23,24,25,26,27)$. In the light of this knowledge, we investigated the relation between pituitary adenomas and ACE genotypes in our study. Since a similar study could not be found in the literature, we did not perform a comparison. We determined that ACE genotypes in tumor tissues and peripheral bloods of 21 cases operated in our study were same and this situation showed us that systemic RAS supported local RAS system. When we investigated immunohistochemical profiles, $50 \%$ I/D, 33\% I/I, 12\% D/D polymorphism was determined in the patients with prolactinoma and 50\% I/I, 25\% I/D, 25\% D/D polymorphism was determined in the patients with mixed adenoma $(\mathrm{GH}+\mathrm{Prl})$. Different distribution polymorphisms were observed in the cases with nonfunctional adenoma and GH adenoma. Presence of D/D genotype in our cases secreting $\mathrm{FSH} / \mathrm{LH}$ supports the view of Deschepper that ACE is present in gonadotropes much more. Presence of D/D polymorphism in our case with ACTH secreting adenoma and presence of $D / D$ in the plurihormonal $(\mathrm{Prl}+\mathrm{GH}+\mathrm{ACTH})$ case is suggesting whether ACTH has an effect in homozygote deletion or not. Although there is no statistical significant difference between immunohistochemical profile and ACE genome deletion, presence of high rate of deletion in cases with adenoma is challenging. Again despite there is no statistical significant difference between ACE genotypes of tumor volumes and grades, presence of higher rate of $D$ allele frequency especially in Grade 3 and 4 patients compared to Grade 1 and 2 requires further investigations regarding ACE genome expression and tumoral angiogenesis.

In conclusion, presence of a higher rate of ACEgenome deletion in patients with pituitary adenomas and especially grade 3-4 adenomas suggests that ACE genome polymorphism may be a risk factor for the development of pituitary adenomas. 


\section{REFERENCES}

1. Becú-Villalobos D, Lacau-Mengido IM, Thyssen SM, BecúVillalobos D, Lacau-Mengido IM, Thyssen SM, Díaz-Torga GS, Libertun C: Effects of LHRH and ANG II on prolactin stimulation are mediated by hypophysial AT1 receptor subtype. Am J Physiol 266:274-278, 1994

2. Boggild $M D$, Jenkinson $S$, Pistorello $M$, Boscaro $M$, Scanarini M, McTernan P, Perrett CW, Thakker RV, Clayton RN: Molecular genetic studies of sporadic pituitary tumors. J Clin Endocrinol Metab 78: 387-392, 1994

3. Botelho $\mathrm{CH}$, Magalhães AV, Mello PA, Schmitt FC, Casulari LA: Expression of p53, Ki-67 and c-erb B2 in growth hormoneand/or prolactin-secreting pituitary adenomas. Arq Neuropsiquiatr 64:60-66, 2006

4. Deschepper CF: The renin-angiotensin system in the pituitary gland. Trends Endocrinol Metab 2:104-107, 1991

5. Deschepper CF, Ganong WF: Distribution of angitensinogen immunoreactivity in rat anterior pituitary glands. Proc Soc Exp Biol Med 197: 304-309, 1991

6. Haiman CA, Henderson SO, Bretsky P, Kolonel LN, Henderson $B E$ : Genetic variation in angiotensin I- converting enzyme (ACE) and breast cancer risk: The multiethnic cohort. Cancer Res 63:6984-6987, 2003

7. Hii SI, Nicol DL, Gotley DC, Thompson LC, Green MK, Jonsson JR: Captopril inhibits tumour growth in a xenograft model of human renal cell carcinoma. Br J Cancer 77: 880-883, 1998

8. Hubert C, Houot AM, Corvol P, Soubrier F: Structure of the angiotensin I-converting enzyme gene: Two alternate promoters correspond to evolutionary steps of a duplicated gene. J Biol Chem 266: 15377-15383, 1991

9. Kakar SS, Sellers JC, Devor DC, Musgrove LC, Neill JD: Angiotensin II type-1 receptor cDNAs; differential tissue expression and hormonal regulation. Biochem Biophys Res Commun 183:1090-1096, 1992

10. Koh WP, Yuan JM, Sun $C L$, van den Berg D, Seow $A$, Lee HP, Yu MC. Angiotensin l-converting enzyme (ACE) gene polymorphism and breast cancer risk among Chinese women in Singapore. Cancer Res 63:573-578, 2003

11. Lenkei Z, Nuyt AM, Grouselle D, Corvol P, Llorens-Cortès $C$ : Identification of endocrine cell populations expressing the AT1B subtype of angiotensin II receptors in the anterior pituitary. Endocrinology 140:472-477, 1999

12. Lever AF, Hole DJ, Gillis CR, McCallum IR, Mclnnes GT, MacKinnon PL, Meredith PA, Murray LS, Reid JL, Robertson JW: Do inhibitors of angiotensin-I-converting enzyme protect against risk of cancer? Lancet 352:179-184, 1998

13. Medeiros R, Vasconcelos A, Costa S, Pinto D, Lobo F, Morais A, Oliveira J, Lopes C: Linkage of angiotensin I-converting enzyme gene insertion/deletion polymorphism to the progression of human prostate cancer. J Pathol 2004: $330-335,2004$
14. Moskowitz DW: Is angiotensin I-converting enzyme a"master" disease gene. Diabetes Technol Ther 4: 683-711, 2002

15. Reddy MK, Baskaran K, Molteni A: Inhibitors of angiotensinconverting enzyme modulate mitosis and gene expression in pancreatic cancer cells. Proc Soc Exp Biol Med 210: 221-226, 1995

16. Rigat B, Hubert C, Corvol P, Soubrier F: PCR detection of the insertion/deletion polymorphism of the human angiotensin converting enzyme gene (DCP1)(dipeptidyl carboxypeptidase 1). Nucl Acids Res 20:1433, 1992

17. Rigat B, Hubert C, Alhenc-Gelas F, Cambien F, Corvol P, Soubrier F: An insertion/deletion polymorphism of the human angiotensin converting enzyme gene accounting for half the variance of serum enzyme levels. J Clin Invest $86: 1343-1346,1990$

18. Sanvitto GL, Jöhren O, Häuser W, Saavedra JM: Water deprivation upregulates ANG II AT1 binding and mRNA in rat subfornical organ and anterior pituitary. Am J Physiol 273:156-163, 1997

19. Sobel D, Vagnucci A: Angiotensin II mediated ACTH release in rat pituitary cell culture. Life Sci 30:1281-1286, 1982

20. Selman WR, Laws ER Jr, Scheithauer BW, Carpenter SM: The occurrence of dural invasion in pituitary adenomas. J Neurosurg 64:402-407, 1986

21. Small W Jr, Molteni A, Kim YT, Taylor JM, Chen Z, Ward WF: Captopril modulates hormone receptor concentration and inhibits proliferation of human mammary ductal carcinoma cells in culture. Breast Cancer Res Treat 44:217-224, 1997

22. Soubrier F, Alhenc-Gelas F, Hubert C, Allegrini J, John M, Tregear G, Corvol P: Two putative active centers in human angiotensin I-converting enzyme revealed by human molecular cloning. Proc Natl Acad Sci USA 85:9386-9390, 1988

23. Spinedi E, Rodriguez G: Angiotensin II and adrenocorticotropin release: Mediation by endogenous corticotropin-releasing factor. Endocrinology 119: 1397-1402, 1986

24. Steele MK, Brownfield MS, Ganong WF: Immunocytochemical localization of angiotensin immunoreactivity in gonadotropes and lactotropes of the rat anterior pituitary gland. Neuroendocrinology 35:155-158, 1982

25. Steele MK, McCann SM, Negro-Vilar A: Modulation by dopamine and estradiol of the central effects of angiotensin II on anterior pituitary hormone release. Endocrinology 111:722-729, 1982

26. Volpert OV, Ward WF, Lingen MW, Chesler L, Solt DB, Johnson MD, Molteni A, Polverini PJ, Bouck NP: Captopril inhibits angiogenesis and slows the growth of experimental tumors in rats. J Clin Invest $98: 671-679,1996$

27. Zhang $X$, Horwitz GA, Heaney AP, Zhang $X$, Horwitz GA, Heaney AP, Nakashima M, Prezant TR, Bronstein MD, Melmed $\mathrm{S}$ : Pituitary tumor transforming gene (PTTG) expression in pituitary adenomas. J Clin Endocrinol Metab 84:761-767, 1999 